\section{New Mexico State University has} received an award of $\$ 127,893$ from the National Endowment for the Humanities (NEH) Division of Preservation and Access to create a comprehensive and current bibliography of almost 12,000 graduate theses and dissertations addressing American Indian topics. The twoyear project will facilitate the work of tribal libraries collecting information on their own tribe and region. It will build on two previous editions of The American Indian in Graduate Studies by Frederick and Alice Dockstader, published by the Museum of the American Indian in 1957 and 1974.

\section{Image Permanence Institute (IPI), a} facility in the College of Imaging Arts and Sciences at Rochester Institute of Technology, has received a $\$ 750,000$ grant from the Andrew W. Mellon Foundation. The funds are intended to strengthen and extend the impact of IPI's research program in preserving collections of imaging materials and other media. The grant, which will be used over a five-year period, will be used to explore new areas of research, collaborate with other laboratories, create preservation tools and publications, upgrade and maintain equipment, expand laboratory space, add staff, and increase staff salaries.

\section{The Massachusetts Institute of Tech-} nology (MIT) Libraries received a gift of $\$ 250,000$ from an anonymous alumnus. The gift will support the creation of the Preservation Services Laboratory - the first phase of the libraries' new Preservation Center. The benefactor was interested in supporting something at MIT that was worthwhile but not an obvious choice for other donors.

\section{Cornell University has received a}

$\$ 228,000$ grant from the National Endowment for the Humanities to preserve and catalog its unique collection of rare books and manuscripts documenting the history of the persecution of witches in Europe. The persecutions, which took place in Europe from the 15 th to the 17 th centuries, are well documented in books and manuscripts that range from orthodox religious tracts to handwritten transcripts of witchcraft trials. Most of the more than 3,600 titles in Cornell's collection were acquired in the 1880 s by Andrew Dickson White, the university's first president. The grant will enable Cornell to preserve on microfilm approximately twothirds of the collection. In addition to creating microfilm copies, catalog records for the microfilmed titles will be converted to machine-readable form, providing online bibliographic access for the first time.

\section{Acquisitions}

\section{The Fletcher Collection, a set of more} than 1,500 books, periodicals, and rare manuscripts dealing with late 19th-century British literature, were acquired by Arizona State University's (ASU) Hayden Library. Ian Fletcher was a professor of English at Reading University in England and taught in ASU's English department from 1982 to 1987 as a visiting professor. During this time, he helped build Hayden Library's collection of late 19th-century British literature. The Fletcher collection includes important collections of poetry from John Gray, Lionel Johnson, and Michael Field; fiction from such notable figures as Barry Pain, George Egerton, G. S. Street, and H. D. Lowry; and issues of many periodicals, including the Acorn, Hobby Horse, and the Savoy.

\section{The library of Jessamyn West, author of} Friendly Persuasion, and an alumnus, has been acquired by Whittier College. The library consists of 6,000 volumes and supplements the collection of her manuscripts given to the college 20 years ago. The books are the primary resources from which she drew in writing her novels. Among the non-book

Ed. note: Send your news to: Grants \& Acquisitions, C\&RL News, 50 E. Huron St., Chicago, IL 60611-2795; e-mail: ayoung@ala.org. 
items are the letters written to West by her mother during her convalescence from tuberculosis.

\section{Agift of rarebooks, manuscripts, Eastern}

thought, scholarly works, and modern art was donated by a 1981 graduate of Hollins University's creative writing program. The gift, appraised at nearly $\$ 500,000$, was given by Barry Jones, an antiquarian bookseller in Chapel Hill, North Carolina. Among the works in the collection are first editions of George Eliot's Middle March, signed books and broadside poems by Robert Penn Warren, a signed copy of Robert Frost's first book Nortb to Boston, and books by many of the writers who have been associated with the university as faculty, lecturers and students, including Richard Dillard, Howard Nemerov, Louis Rubin, Jill McCorkle, Lee Smith, and Madison Smartt Bell.

\section{E. L. Doctorow, author of such award-} winning novels as Ragtime, Billy Bathgate, and World's Fair, has donated all of his papers, including all manuscripts, drafts, galleys, screenplays, memorabilia, notes and correspondence, to New York University's (NYU) Fales Library, the university's major rare book repository. The collection will be named the E. L. Doctorow Papers. Doctorow, whose most recent book, City of God, was published last year, has taught at NYU since 1982. He holds the Lewis and Loretta Glucksman Chair of English and American Letters at the university.

\section{The literary archive of British poet and}

critic 'Tom Paulin has been acquired by Emory University. He has taught at the University of Nottingham, and currently is a lecturer in English at Hertford College, Oxford. Paulin is also host of the BBC's book program "Late Review." His poetry has been collected in a number of volumes: $A$ State of Justice (Poetry Book Society Choice); The Strange Museum; Liberty Tree; Fivemiletown; Selected Poems, 1972-1990; and The Wind Dog (Poetry Book Society Choice). Paulin is also a highly regarded literary critic. Among his works of criticism are: Minotaur: Poetry and the Nation State; Writing to the Moment: Selected Critical Essays, 1980-1996: and The Day Star of Liberty: William Hazlittís Radical Style.

\section{Photographs by photographer Brett} Weston (1911-93), son of photographer Edward Weston, have been acquired by the J. Paul Getty Museum. The 256 photographs were a gift from Christian Keesee, an art collector and chair of American Bancorp of Oklahoma. The rare prints date from the 1930 s through the 1970s. Weston created striking urban documentary photographs of New York and San Francisco in the 1930s and 1940s, but he was largely concerned with portraying the natural landscape. In a dramatic gesture on his 80 th birthday, Weston burned all but a dozen of his own negatives to confirm his belief that a negative should be printed only by the person who created it.

\section{The papers of Frederick W. Voget,} anthropologist and ethnologist, have been donated to the University of Montana. The Voget papers, which include field notes and an extensive photograph collection taken between 1938 and 1941, document his work with the Crow Indians of eastern Montana. Voget was a faculty member at Montreal's McGill University, the University of Arkansas, the University of Toronto, and Southern Illinois University. His dissertation, "The Shosoni Crow Sun Dance" was published in 1984 as the first full-length authoritative treatment of that important Crow ceremony. He also published numerous other books and articles during his career, including "They Call Me Agnes: A Crow Narrative Based on the Life of Agnes Yellowtail Deernose" and "A History of Ethnology."

\section{IMLS grant deadlines}

Following are 2002 deadline dates for the Institute of Museum and Library Services (IMLS) programs:

- National Leadership Grants from Libraries (including Education and Training, Research and Demonstration, and Preservation or Digitization)-February 1

- Library-Museum CollaborationsApril 1

- Native American Library Services-March 1

- Native Hawailan Library Services-May 1 